VAROLO, Flávia Renata da Silva; RIBEIRO, Arilda Ines Miranda; FELIX, José Luís. Trajetória educacional dos imigrantes alemães no interior do Estado de São Paulo. Uma escola alemã na colônia Riograndense: 1922-1938 (Maracaí/CruzáliaSP). Jundiaí: Paco Editorial, 2015.

\title{
TERRA, EDUCAÇÃO E IMIGRAÇÃO: \\ UMA ESCOLA NA COLÔNIA DE ALEMÃES NO INTERIOR DO ESTADO DE SÃO PAULO
}

Thiago Henrique Sampaio ${ }^{1}$

Quando estudamos movimentos migratórios, temos que entender as tentativas de implantação de uma cultura de imigrantes, em seus novos espaços de convívio, como uma forma de continuação das experiências de sua terra de origem. Dentro dessa perspectiva, a obra Trajetória educacional dos imigrantes alemães no interior do Estado de São Paulo apresentou um panorama da colônia Riograndense e sua escola alemã.

Na apresentação José Luís Felix, professor da Faculdade de Ciências e Letras (UNESP/Assis), salientou a importância do papel de um sistema escolar dentro da comunidade de imigrantes alemães no Brasil. Dessa forma, a história da escola da colônia Riograndense confunde-se com a trajetória da própria localidade. O recorte temporal apresentado na obra é de 1922 a 1938, na região dos municípios de Cruzália e Maracaí. O ano final da escolha da pesquisa deve-se à deterioração da Escola Alemã, durante o Estado Novo com suas medidas educacionais.

$\mathrm{Na}$ introdução, Flavia Renata da Silva Varolo, apresentou suas motivações ao escrever a obra e seu contato com a cultura e língua alemã durante sua trajetória de formação. Seu livro usou como metodologia a História Oral, articulando-se com a História Cultural, durante toda a obra. Suas fontes são

1 Mestrando pelo Programa de Pós-Graduação em História pela Faculdade de Ciências e Letras (UNESP/Assis). 
fotografias, textos, e narrativas, dos moradores da colônia e pessoas que passaram pela Escola Alemã.

O livro é resultado de sua dissertação de Mestrado em Educação, $A$ educação alemã na colônia Riograndense: 1922-1938 (Maracaí/Cruzália-SP) defendida, em 2010, no Programa de Pós-Graduação em Educação da Faculdade de Ciências e Tecnologia de Presidente Prudente (UNESP/Presidente Prudente).

No primeiro capítulo, $O$ imigrante alemão no solo brasileiro, a autora mostrou o início da vinda dos alemães em território nacional. Isso era desencadeado por motivos como má distribuição de terras, problemas econômicos, e altos impostos, em suas localidades. Para a pesquisadora, o início do movimento migratório alemão para o Brasil começou com a vinda da família real portuguesa, em 1808, que trouxe alguns alemães em sua comitiva.

O aumento do fluxo da população alemã ao Brasil iniciou-se em 1820, com um decreto de D. João VI para incentivar a entrada de indivíduos europeus, com a finalidade de gerar o branqueamento da população do território. Entre 1822 a 1826, a vinda de alemães ganhou força com a Imperatriz Leopoldina, filha do imperador da Áustria, Francisco I.

No caso do Estado de São Paulo, a imigração alemã pode ser dividida em quatro fases: a primeira, de 1827 a 1849, devido a políticas imperiais adotadas no país; a segunda, de 1850 a 1870, acarretado às agitações sociais nos territórios alemães; a terceira, de 1870 a 1945, motivada por parcerias entre as administrações do estado com companhias; e a quarta, de 1945 aos dias de hoje. Na década de 1930, o fluxo de alemães se intensificou para o Estado devido a política de branqueamento adotado durante o Estado Novo.

Nas décadas de 1920 a 1930, a educação brasileira não penetrava nas grandes camadas populares, isso incluiu os imigrantes em território nacional. A educação pública era essencialmente aristocrática e patriarcal. Com o movimento da Escola Nova, buscou-se uma renovação escolar através do discurso progressista e liberal.

Durante a Era Vargas, aconteceram mudanças formais e substanciais na educação através de algumas medidas como a criação do Ministério da Educação e Saúde (1930), a Reforma Francisco Campos (1931), e a Reforma Gustavo Capanema (1942). Com uma pasta própria para assuntos educacionais, 
ocorreram a formação do Conselho Nacional de Educação, que buscou a organização do ensino superior, secundário e comercial; a organização da Universidade do Rio de Janeiro, e a adoção de medidas no regime universitário.

No capítulo seguinte, Uma colônia de alemães no interior do Estado de São Paulo, a autora tratou da formação da Colônia Riograndense, em 1922. A população da localidade era originária da Alemanha, Áustria, Suíça e de alemães que já estavam no Brasil e se mudaram para a região. Para escrever sobre a história da colônia foi utilizada documentação oficial, depoimentos e diários de habitantes. O nome da região origina-se da influência de colonos do Rio Grande do Sul.

Durante o início da colônia aconteceu propaganda para a vinda de alemães a área. Esse marketing era enganoso, pois divulgava terras planas e próprias para a agricultura. Ao chegarem na localidade, os colonos deveriam abrir matas para a construção de casas e cultivos. Além disso, a viagem da Alemanha para o Brasil era extremamente cansativa e penosa, principalmente para crianças e idosos. Muitos, que tentaram vir, morreram devido a problemas na viagem e causadas por tifo.

A colônia Riograndense passou por três núcleos de colonização: em 1922, na região central da localidade; em 1924, começou um segundo núcleo, formado por habitantes de maioria católica e com grandes propriedades; e em 1929, uma região de população majoritária de gaúchos em torno da Fazenda Galvão.

As mulheres e crianças ajudavam na derrubada de matas para a criação de áreas cultiváveis e habitacionais na colônia. A agricultura era de produtos de subsistência: mandioca, milho e feijão. Entretanto, a economia da colônia ganhou força com a comercialização de alfafa, produto ficou em alta até a década de 1950. Na década de 1960, a alfafa foi substituída pelo cultivo de trigo e soja. A localização da área colonial era de fácil acesso à estrada de ferro (Sorocabana), possibilitando um rápido escoamento de sua produção.

Católicos e luteranos conviviam na localidade. Desde o início do processo de colonização as igrejas eram construídas. Desta forma, fé e religião eram uma força para os colonos superarem as dificuldades das mudanças.

No último capítulo, A educação alemã na colônia rio-grandense: escolas, clubes e práticas culturais, a autora buscou demonstrar o papel primordial 
desempenhado pela educação no processo de inserção dos imigrantes alemães. A educação nas colônias, na maioria das vezes, era responsabilidade dos seus próprios moradores, que construíram escolas e contratavam professores devido à ausência de investimentos do Estado nas localidades. Na colônia Riograndense não foi diferente.

A Escola Alemã da colônia Riograndense era no meio rural e mista (meninos e meninas frequentavam). A primeira escola foi construída em madeira e após um incêndio, em 1926, uma nova escola foi inaugurada. No currículo escolar estavam presentes o catecismo, a bíblia, a escrita e a aritmética. 0 material didático era de língua alemã adaptada à realidade brasileira. Seu programa curricular era flexível e diversificado para o momento.

O professor possuía responsabilidades além da escola, como o desenvolvimento de atividades culturais e religiosas, além da importância econômica para a localidade. A manutenção do colégio ficou a cargo dos colonos (prédio e salário de professor).

Os espaços educacionais não se restringiram apenas à escola, pois os autores do livro demonstram que outros espaços sociais, como os clubes e igrejas, tinham importância na formação educacional das crianças e jovens, principalmente após a perseguição e preconceito a alemães, desencadeados após a Segunda Guerra Mundial.

Com a Reforma de Gustavo Capanema teve início o fim da escola, pois houve a implementação de escolas públicas na colônia Riograndense. Esta reforma colocou como obrigatória o ensino do português nas escolas públicas. $\mathrm{O}$ número de alunos da Escola Alemã diminuiu com o início das reformas educacionais do período do Estado Novo

Durante a Segunda Guerra Mundial, os habitantes da colônia sofreram com associação ao nazismo. Muitos imigrantes alemães foram perseguidos pela polícia, tiveram suas casas invadidas e alguns bens confiscados.

Com o passar do tempo, aprender alemão perdeu importância entre os colonos, pois começaram a se considerar integrados à sociedade brasileira. Este processo de aculturação da colônia foi movido por vários fatores, entre eles a Segunda Guerra Mundial, nacionalização do ensino e casamento de seus habitantes com pessoas de fora da colônia. Entretanto, micro-resistências dos 
habitantes se mantinham, como a preservação da língua dentro dos espaços do lar.

Em suas considerações finais, a autora salientou a relação construída dos imigrantes com a sociedade brasileira, como eram vistos por nós e como entendiam o Brasil. A colônia alicerceava-se na escola e na igreja, sendo o colégio um lugar de construção da cultura, da língua e cidadania.

Com a mudança de hábitos na colônia, ocorreram alterações também na Escola Alemã. Ela ficou responsável pela formação dos filhos dos colonos para a obtenção de postos de trabalho melhores que de seus pais. Entretanto, na medida em que se exportou mão de obra qualificada, se impôs um fim lento e gradual da colônia e, com isso, de sua escola.

A obra Trajetória educacional dos imigrantes alemães no Estado de São Paulo é ímpar ao mostrar o papel da educação como sinônimo de oportunidades a imigrantes em uma localidade nova. O livro aborda a coesão de um povo para a manutenção da sua cultura e de suas práticas sociais, distantes de sua pátria mãe. Com uma escrita agradável e esclarecedora, a autora faz o leitor analisar o papel da educação como algo fortalecedor de uma comunidade em prol da prosperidade coletiva e manutenção de suas raízes histórico-culturais.

Recebido em 11 de dezembro de 2016 Aprovado em 28 de dezembro de 2017 